\title{
Impact of Integrated Fertilization (Organic and In-Organic) on Grain Yield of Maize
}

\author{
Muhammad Bilal $^{1}$, Muhammad Tayyab ${ }^{1}, \operatorname{Irfan}_{\mathrm{Aziz}}{ }^{1}$, Abdul Basir $^{2}$, Bilal Ahmad $^{1}$, Umair Khan $^{1}$, \\ Muhammad Zahid ${ }^{3}$, Naveed Ali ${ }^{1}$ \\ ${ }^{1}$ Faculty of Crops \& Food Sciences, PMAS-Arid Agriculture University, Rawalpindi, Pakistan \\ ${ }^{2}$ Department of Agronomy, University of Swabi, Khyber Pakhtunkhwa, Pakistan \\ ${ }^{3}$ Faculty of Crop Production Sciences, The University of Agriculture, Peshawar, Pakistan
}

Email address:

mbilal4949@gmail.com (M. Bilal)

\section{To cite this article:}

Muhammad Bilal, Muhammad Tayyab, Irfan Aziz, Abdul Basir, Bilal Ahmad, Umair Khan, Muhammad Zahid, Naveed Ali. Impact of Integrated Fertilization (Organic and In-Organic) on Grain Yield of Maize Crop. Agriculture, Forestry and Fisheries.

Vol. 6, No. 5, 2017, pp. 178-183. doi: 10.11648/j.aff.20170605.16

Received: August 15, 2017; Accepted: September 6, 2017; Published: October 2, 2017

\begin{abstract}
Organic manure is a commendable organic fertilizer, as it contains nitrogen, phosphorus, potassium and other essential nutrients. The most important factors responsible for low yield are inappropriate crop nutrition management and poor soil fertility. The field experiment was performed to evaluate the impact of different fertilizer (organic and inorganic) on yield and yield components of maize at Agriculture Research Station Swabi, Khyber Pakhtunkhwa during summer season 2014. The experiment was laid out in a randomized complete block design (RCBD) replicated three times. Data was recorded on seven quantitative traits i.e. days to tasseling, plant height $(\mathrm{cm})$, leaf area, number of grains $\mathrm{cob}^{-1}$, biological yield $\left(\mathrm{kg} \mathrm{ha}^{-1}\right), 1000$ grain weight $(\mathrm{g})$ and grain yield $\left(\mathrm{kg} \mathrm{ha}^{-1}\right)$. All treatments were significantly affected by the applied treatments with the exception of days to tasseling. The treatment poultry manure gave maximum leaf area whereas minimum leaf area was obtained in control. Maximum plant height $(\mathrm{cm})$, number of grains $\mathrm{cob}^{-1}, 1000$-grain weight $(\mathrm{g})$, biological yield $\left(\mathrm{kg}\right.$ ha $\left.{ }^{-1}\right)$, and grain yield $\left(\mathrm{kg} \mathrm{ha}^{-1}\right)$ was obtained in compost applied treatment followed by poultry manure. Whereas minimum plant height $(\mathrm{cm})$, grains $\mathrm{cob}^{-1}$, biological yield $\left(\mathrm{kg} \mathrm{ha}^{-1}\right)$, 1000-grain weight $(\mathrm{g})$ and grain yield $\left(\mathrm{kg} \mathrm{ha}^{-1}\right)$ was obtained in control. The results depicted that organic fertilizer gave excellent response for yield and its related traits of maize crop as compared to inorganic fertilizer.
\end{abstract}

Keywords: Maize, Compost, Organic and Inorganic Fertilizers, Grain Yield

\section{Introduction}

Maize (Zea mays L.) is third most important cereal crop after wheat and rice [7] and also have a unique position in the national economy of Pakistan, as it is used as food, feed and fodder purpose. Out of the total production of maize twothird is used for livestock feed or for commercial starch and oil extraction [10]. The maize grain have a nutritious value which is protein $(10.4 \%)$, fats $(4.5 \%)$, starches $(71.8 \%)$, vitamins and minerals like calcium, phosphorous and Sulphur [9]. In contrast with developed countries of the world, the yield of the maize having higher yielding ability is very low. Even many of the advanced and higher yielding varieties and cultivars are produced but could not achieved the possible yield. Typically this is because of careless of the farmers toward the proper application of nutrients.

Nitrogen plays an important role for higher yield production of wheat and maize [1]. In semiarid regions the total Carbon, nitrogen and phosphorus contents of the topsoil were decreased due to continues cultivation [4]. Inappropriate crop nutrition management and poor soil fertility are the most important factors responsible for low yield. Crop productivity and soil fertility significantly increased due to nitrogen application [5]. In Pakistan mostly farmers depend upon synthetic fertilizer application to get rid of nutrients deficiency. Due to high expenses on fertilizer 
farmer cannot apply sufficient fertilizer. So, the crop not obtained balanced proportion of nutrients consequently causes lower production. Under such conditions organic fertilizer application plays important role to maintain the fertility of soil as well as crop productivity [5] [20]. Under semiarid conditions crop productivity increased with the application of organic fertilizer [13].

Organic manure and cattle dung increased root growth of maize and enhance the extracted soil water more efficiently which ultimately increased grain yield [22]. Currently poultry manure is an excellent organic fertilizer, as it contains high nitrogen, phosphorus, potassium and other essential nutrients. In contrast to chemical fertilizer, it adds organic matter to soil which improves soil structures, nutrient retention, aeration, soil moisture holding capacity and water infiltration [6]. Poultry manure supplies sufficient amount of phosphorus to plants than other organic manure sources [10]. The foregoing review showed that synthetic fertilization degrades soil organic matter with time due to its preferable application. Accordingly, Present study was planned to assess the impact and comparison of organic and inorganic fertilizers on yield and yield components of maize crop.

\section{Materials and Methods}

\subsection{Experimental Site}

Agriculture Research Station is located in the south west of the district Swabi at $34^{\circ} 7^{\prime} 12 \mathrm{~N}$ and $72^{\circ} 28^{\prime} 12 \mathrm{E}$, altitude of 316 meters (1040 feet), and with an elevation of 330 meters above sea level.

\subsection{Weather Data}

The climate of the experimental site is classified as warm and temperate. In winter, there is much less rainfall in Swabi than in summer. This location is classified as (Cwa) by Köppen and Geiger. The average annual temperature is $22.2^{\circ} \mathrm{C}$ in Swabi. About $639 \mathrm{~mm}$ of precipitation falls annually.

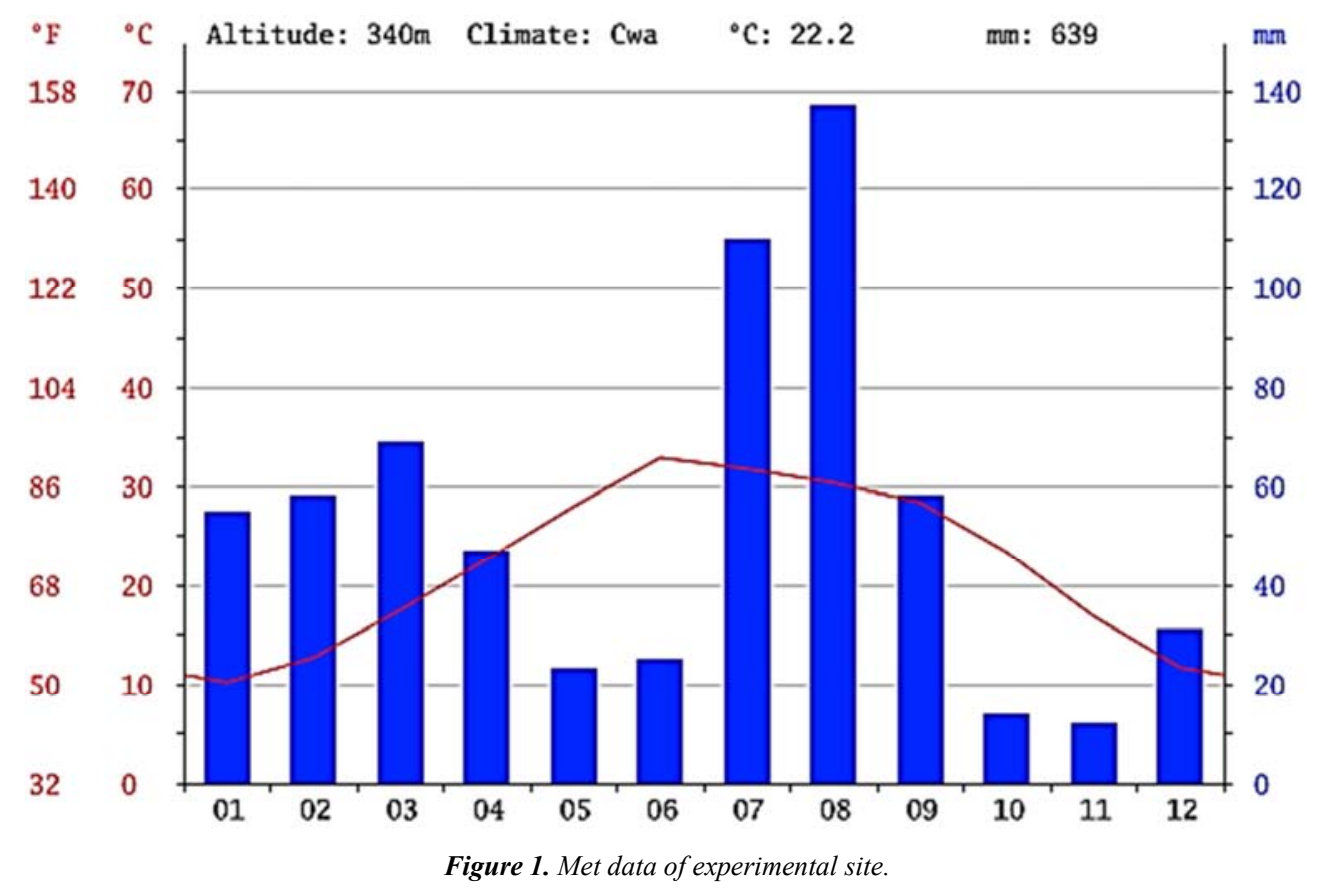

\subsection{Experimental Design}

The experiment was laid out in RCB design, having five different treatments, replicated three times at the Agriculture Research Station, Anbar Swabi, during growing season of 2014. Spatial arrangement was done using $75 \mathrm{~cm}$ row to row and $30 \mathrm{~cm}$ plant to plant distance. Each plot was $3 \times 3 \mathrm{~m}^{2}$ with four rows, having 10 plants in each row.

\subsection{Field Management}

Before sowing and after deep ploughing, primary and secondary tillage was done in the field each followed by planking. After tillage practices, ridges were made at $75 \mathrm{~cm}$ apart. Sowing of good and viable seed of maize variety (Babar) was done on $7^{\text {th }}$ August 2014. After sowing, irrigation was applied according to field requirement throughout the season. Experimental treatments comprised of four organic and inorganic fertilizers such as DAP, poultry and farm yard manure and compost. Different fertilizer treatments were $\left(\mathrm{T}_{1}\right)$ control, $\left(\mathrm{T}_{2}\right)$ Compost $625 \mathrm{~kg} \mathrm{ha}^{-1},\left(\mathrm{~T}_{3}\right)$ Poultry manure $833 \mathrm{~kg} \mathrm{ha}^{-1},\left(\mathrm{~T}_{4}\right)$ Farm yard manure $625 \mathrm{~kg}$ $\mathrm{ha}^{-1}$ and $\left(\mathrm{T}_{5}\right)$ DAP $173 \mathrm{~kg} \mathrm{ha}^{-1}$ were applied before sowing. Total 15 plots were made to provide different treatments.

\subsection{Observed Parameters}

The parameters under study during the whole growing season were seven quantitative traits i.e. days to tasseling, plant height $(\mathrm{cm})$, leaf area, grains $\mathrm{cob}^{-1}$, biological yield $(\mathrm{kg}$ $\left.\mathrm{ha}^{-1}\right)$, 1000-grain weight $(\mathrm{g})$ and grain yield $\left(\mathrm{kg} \mathrm{ha}^{-1}\right)$ measured by standard procedure. Days to tasseling was 
calculated by counting days from first emergence till tasseling. Plant height and leaf area was measured by using measuring tape. Crop was harvested after 108 days after sowing whereas 1000-grain weight, numbers of grain per cob was measured to assess the production of the crop. Harvest Index was calculated with the help of formula.

$$
\text { Harvest Index }(\%)=\frac{\text { Grain yield }}{\text { Biological yield }} \times 100
$$

\subsection{Statistical Analysis}

The analysis of variance was performed to test the significant differences between means of various parameters for the application of different fertilizers for the year 2014 of maize growing season using LSD test where level of significance was 0.05 .

\section{Results and Discussion}

\subsection{Days to Tasseling}

The results regarding days to tasseling indicated that application of different manure showed non-significant effect on days to tasseling of maize hybrid Babar. It is clear from data (Figure 2) that days to tasseling was equally delayed in the plots where DAP and Poultry Manure were applied. The maximum days were recorded in the DAP (50.33 days) treated plots followed by Poultry Manure (50) in the control (48.33) plots.

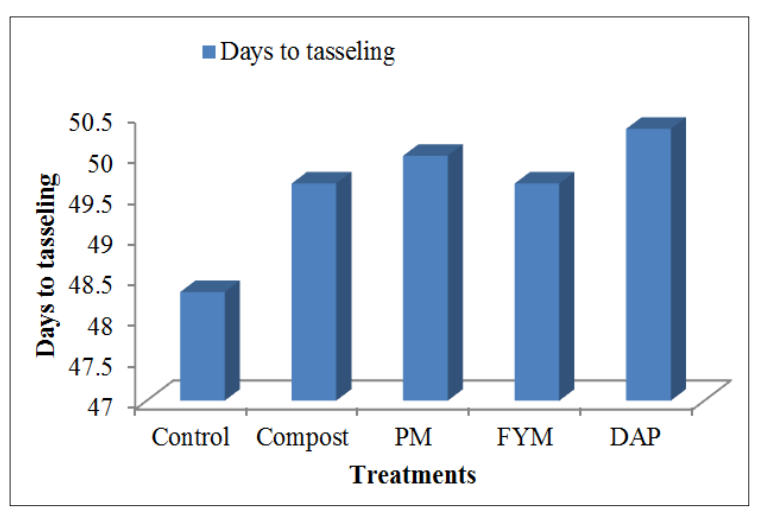

Figure 2. Days to tasseling.

\subsection{Leaf Area (cm)}

Data presented in (Figure 3) indicated significant effect of different organic application on leaf area of maize. The maximum leaf area were recorded in the compost $(355.25 \mathrm{~cm}$ while the minimum leaf areas were recorded in the control $(234.81 \mathrm{~cm})$. The mean value of leaf area in Babar maize hybrid crop was 287.17 to $332.60 \mathrm{~cm}$. our research finding are similar to those of [2] who reported that application of $\mathrm{N}$ fertilizer significantly increased the leaf area plant ${ }^{-1}$ of maize fodder. As increment in leaf area of the crop is the factor to increase biomass production because maximum leaf area absorb more solar radiation and will increase the photosynthesis rate.

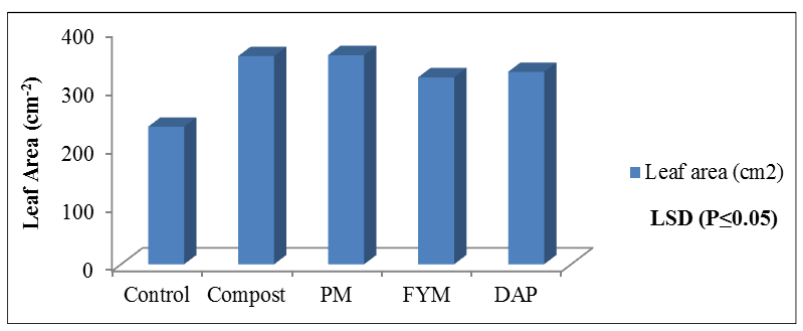

Figure 3. Leaf area $\left(\mathrm{cm}^{-2}\right)$.

\subsection{Plant Height (cm)}

Plant height plays an important role in the final yield of fodder crops. The (Figure 4) depicted plant height significantly affected by both organic and inorganic fertilizers. All the treatments fertilized with organic and inorganic fertilizers produced significantly taller plants as compared to control. Data presented that the plant height were found significant $\mathrm{P}>0.05$. The maximum plant heights were recorded in the compost $(77.133 \mathrm{~cm})$ while the minimum plant heights were recorded in the control (64.667 $\mathrm{cm})$. Our results indicated that increased nitrogen application has pronounced effect in increasing vegetative growth of crop pants. Significant increase in plant height with nitrogenous fertilizers has also been observed in maize by [7].

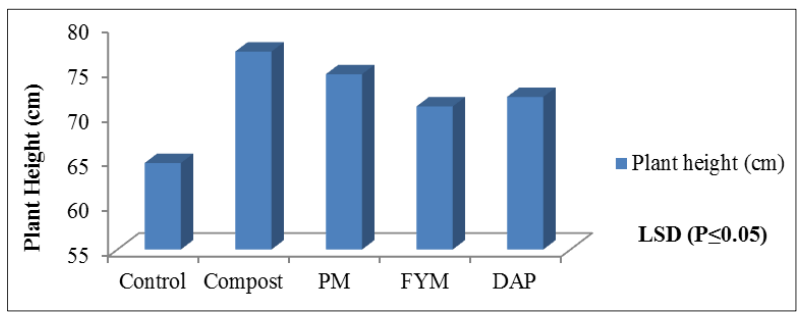

Figure 4. Plant height $(\mathrm{cm})$

\subsection{Number of Grain $\operatorname{Cob}^{-1}$}

Number of grain per cob were found significantly $(\mathrm{P}>0.05)$ different under the effect of organic and inorganic fertilizer on maize crop. The maximum numbers of grain per cob were recorded in compost (451.53) while the minimum numbers of grain (305.00) per cob were recorded in control (Figure 5). This increase in number of grains per cob might be due to availability of Nitrogen at proper time, which is required for better growth and development of plants. Our results are similar to the findings of [15].

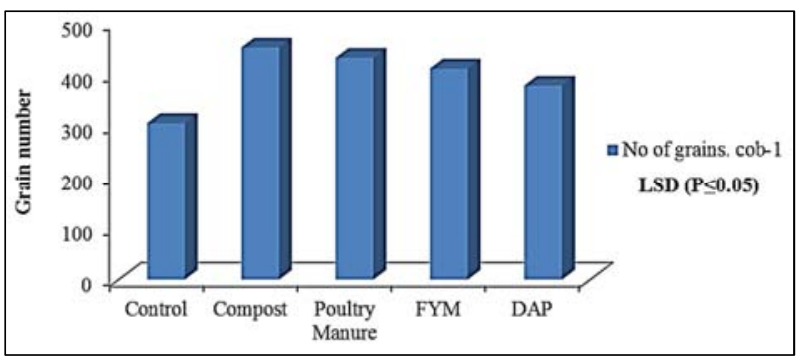

Figure 5. Number of grain $\mathrm{cob}^{-1}$. 


\subsection{0-Grain Weight (g)}

Data presented in (Figure 6) show that 1000-grain weight was significantly affected by different levels of organic and inorganic fertilizers. Maximum 1000- grain weight was recorded in compost $(237.67 \mathrm{~g})$. It is followed by the Poultry Manure which were (216.67 g) and then DAP (205.33) while the minimum grain yield was recorded in control (148.33 g). Our results are in accordance with the findings of [17] and [10]. Furthermore, [10] elaborated that application of poultry manure also make phosphorus available for the maize crop which ultimately positively influence grain filling rate.

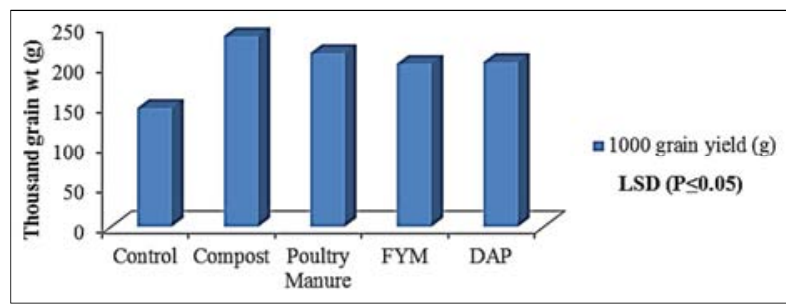

Figure 6. 1000-grain yield (g).

\subsection{Grain Yield $\left(\mathrm{kg} \mathrm{ha}^{-1}\right)$}

Grain yield is a function of interaction among various yield components that were affected differentially by the growing conditions and crop management practices. It is clear from the (Figure 7) that grain yield was significantly affected by the application of different levels of organic and inorganic fertilizers. As regards nutrient resources, different levels of organic and inorganic sources affected grain yield significantly (Figure 7) it was showing that the maximum grain yield was recorded in compost $(2723 \mathrm{~kg})$ while the minimum grain yield was recorded in control $(1695.5 \mathrm{~kg})$. [21] Reported similar observations of getting higher yields of maize grain with combined application of organic and inorganic fertilizers.

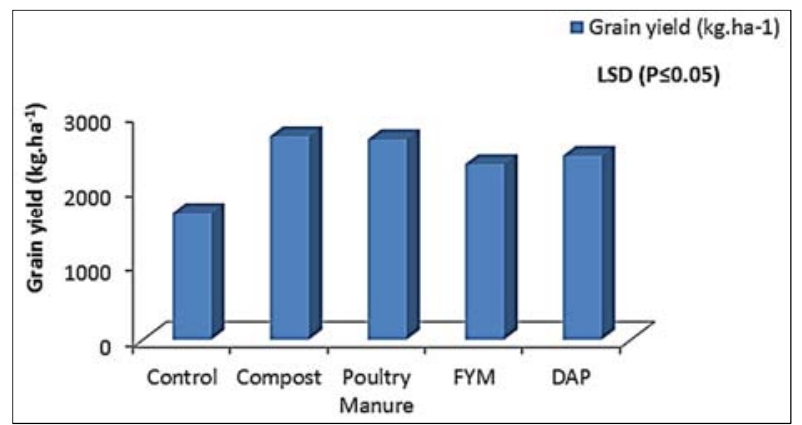

Figure 7. Grain yield $\mathrm{kg} \mathrm{ha}^{-1}$.

\subsection{Biological Yield $\left(\mathrm{kg} \mathrm{ha}^{-1}\right)$}

Biological yield was significantly affected by different levels of organic and inorganic fertilizer. The maximum biological yield was recorded in compost $(7-\mathrm{kg})$ while the minimum biological yield was recorded in control $(4.333 \mathrm{~kg})$ in (Figure 8). At physiological maturity biological yield was recorded after complete sun drying of the harvested crop from each plot and expressed in $\mathrm{kg}$. Our research are similar to those [18] and [16] who reported significant increases in maize grain and straw yields with addition of organic to inorganic fertilizers as compared to no fertilizer.

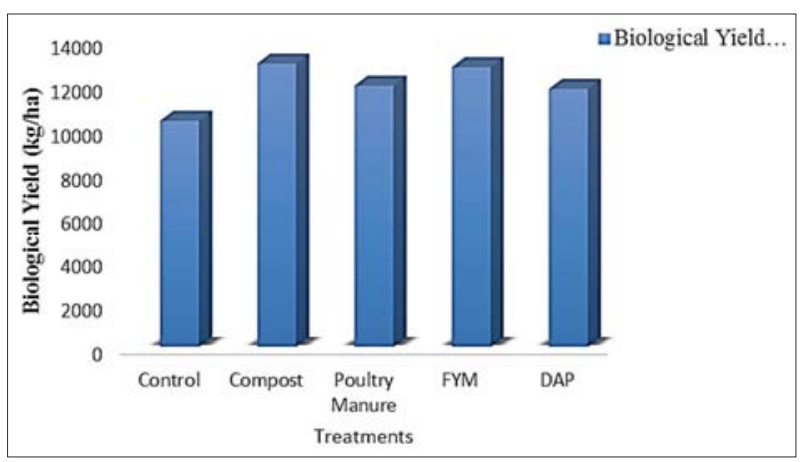

Figure 8. Biological Yield $(\mathrm{kg} / \mathrm{ha})$.

\subsection{Harvest Index (\%)}

The physiological efficiency of a crop plants in converting the photosynthate into grain yield is measured in the form of harvest index. Higher the index value, higher the efficiency of converting dry matter into economic yield. It is clear from the (Figure 9) that harvest index of poultry manure is maximum over the entire treatments while lower for control.

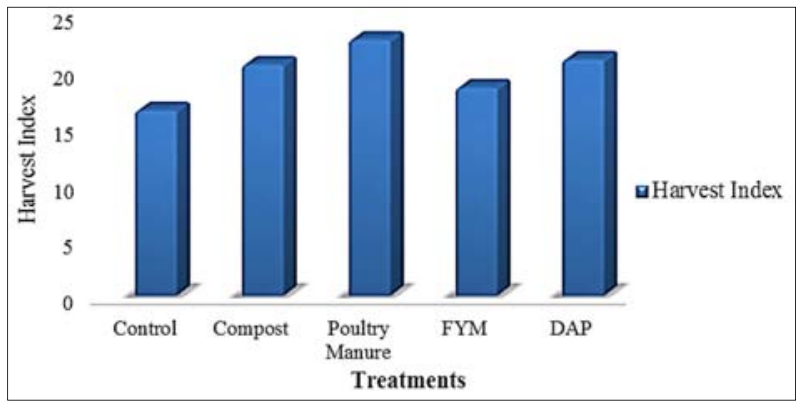

Figure 9. Harvest Index.

\section{Conclusions and Recommendations}

Results reveal that significant differences were observed for most of the traits except days to tasseling and cobs plant ${ }^{-1}$ by the application of different treatments in the study. Maximum cob length, grains $\mathrm{cob}^{-1}$, biological yield, 1000grain weight and grain yield was obtained in the treatment where compost was applied followed by the treatment poultry manure (PM). It was observed in the study that compost and poultry manure were the valuable fertilizers and showed better result on yield and yield related traits of maize crop. It was also observed in the study that organic fertilizer showed positive response to yield and other plant growth traits of maize crop as compared to inorganic fertilizer. Organic farming positively influence all the essential and beneficial nutrients along with the retention of total organic matter. Quantitative increase of organic matter enhance water holding capacity of the soil which helps the nutrients mobility in soil. 


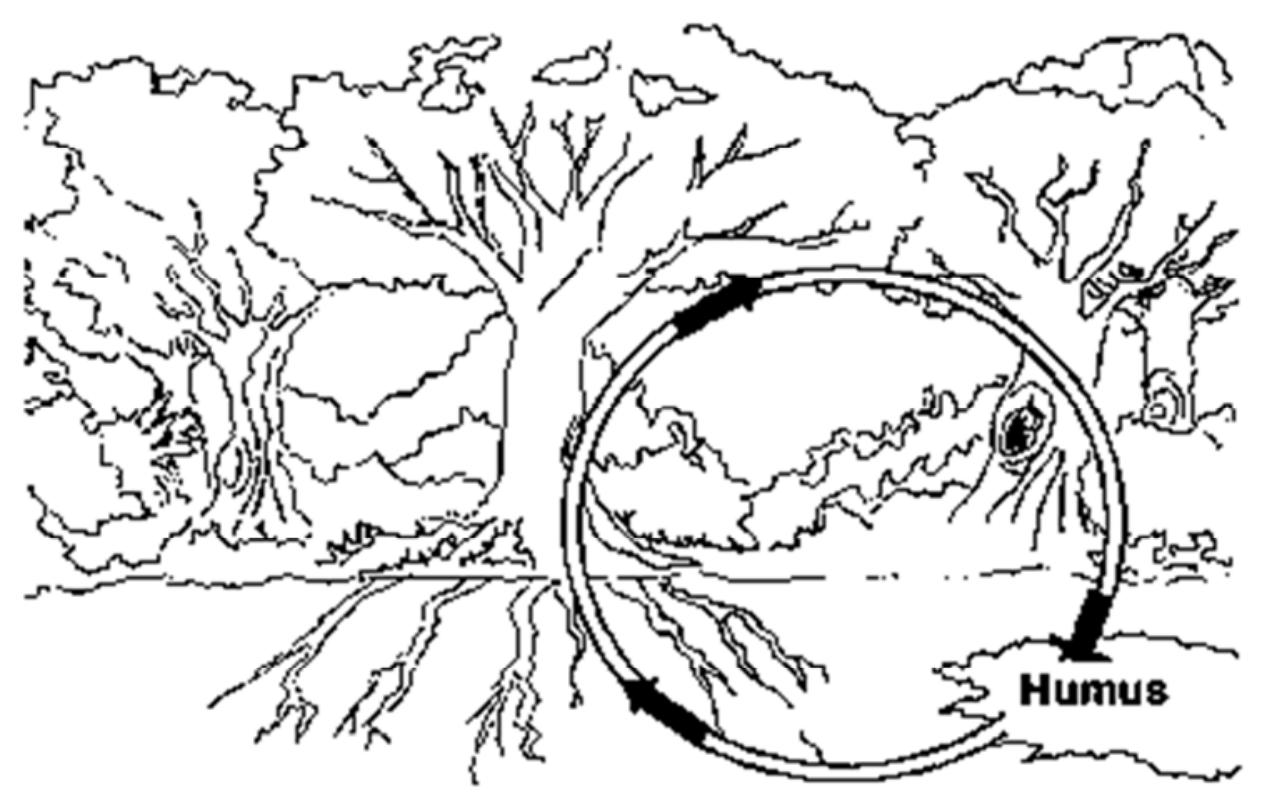

Figure 10. Closed Cycle of Organic Matter.

The above figure shows steady water infiltration rate which eventually decrease surface run-off and soil erosion whereas organic application reduce the evaporation and evade desiccation from the soil surface. Organic application not only maximize crop yield while also prevent stream water from pollution and also helps in underground water recharge.

Besides this, organic fertilization also optimize the biological activity with in the soil. It provide a recycling process of the nutrients which later available for the crops. Bio-chemical processes takes place and accelerate decomposition and transformation of soil organic matter to more stable form called humus. Based on these results, the effect of organic fertilizer on maize crop productivity and soil fertility must be further evaluated before it is recommended to farmers.

\section{References}

[1] Ahmad, N. 2000. Fertilizer scenario in Pakistan: Policies and development In: Proc. Ofconf. Agric. and fertilizer use. 2000. Feb. 15-16, NFDC, Islamabad, 1999.

[2] Ayube, M., A. Tanveer, K. Mahmud, A. Ali and M. Azam. 1999. Effect of nitrogen andphosphorus on the fodder yield and quality of two sorghum cultivars (Sorghumbicolor). Pak. J. Biological Sci. 2 (1): 247-250.

[3] Amanat, A. A., 1998. Effect of variable rates of nitrogen and phosphorus on Growth andyield of maize. M. Sc. Thesis, Department of Agronomy, University ofAgriculture, Faisalabad-Pakistan.

[4] Buschiazzo, D. E., G. G. Hevia and E. N. Hepper. 2000. Cultivation effects on phosphateforms and sorption in loess soils of Argentina. Soil. Sci. 165: 427-436.

[5] Channabasanagowda, N., K. B. Patil, B. N. Patil, J. S. Awaknavar, B. T. Ninganur and R. Hunje. 2008. Effect of organic manures on growth, seed yield and quality ofwheat. Karnataka J. Agric. Sci. 21: 366-368.

[6] Deksissa, T., I. Short and J. Allen (2008). Effect of soil amendment with compost ongrowthand water use efficiency of Amaranth. In: Proceedings of theUCOWR/NIW annual conference: International water resources: challenges forthe 21 st century and water resources education, July 22-24, 2008, Durham, NC.

[7] Desai, S. N. and D. D. Dore. 1980. Performance of forage sorghum varieties (Sorghumbicolor L.) under nitrogen fertilization. Forage Res.

[8] Farooqi, I. H. 1999. Influence of nitrogen and phosphorus on growth, yield and oil contentof two hybrids of maize. $M$. Sc. Thesis, Department Agronomy University ofAgriculture, Faisalabad-Pakistan.

[9] Farhad, W., M. F. Saleem, M. A. Cheema and H. M. Hammad. 2009. Effectof poultrymanure level on the productivity of spring maize (Zea mays L). J. Anim. PlantSci. 19 (3): 122125.

[10] Garg, S. and G. S. Bahla. (2008). Phosphorus availability to maize as influenced byorganic manures and fertilizer $\mathrm{P}$ associated phosphatase activity in soils. Bioresource Technology, 99 (13): 5773-5777.

[11] Gerpacio V R and Pingali P L. (2007). Tropical and Subtropical Maize in AsiaProduction System, Constraints and Research Priorities, CIMMYT, Mexico, ISBN: 978-970-648155-9, pp. 93. s

[12] Habtegebrial K, Singh B, Haile M, Habtegebrial K, Singh B, Haile M. 2007. Impact oftillage and nitrogen fertilization on yield, nitrogen use efficiency of tef (Eragrostistef (Zucc.) Trotter) and soil properties. Soil and Tillage Res. 94 (1): 55-63.

[13] Iqbal A., Amanullah, Iqbal M. (2015). Impact of potassium rates and their applicationtime on dry matter partitioning, biomass and harvest index of maize (Zea mays)with and without cattle dung application. Emir. J. Food Agric. 27: 447453. 
[14] Khalil, I. A. and A. Jan. 2004. Cereal crops cropping technology. National BookFoundation, Islamabad. pp. 169201.

[15] Kumar, A., K. S. Thakur and M. Sandeep. 2002. Effect of fertility levels on promisinghybrid maize under rain fed conditions of Himachal Pradesh. Indian. J. Agron. 47: 526530 .

[16] Mishra, V. K. 2000. Water expense and nutrient use efficiency of wheat and winter maizeas influenced by integrated nutrient management. Agropedology. 10 (1): 1-5.

[17] Ma, B. L., L. M. Dwyer and E. G. Gregorich (1999). Soil nitrogen amendment effects onnitrogen uptake and grain yield of maize. Agro. J. 9: 650-656.

[18] Negi, S. C. and G. Mahajan. 2000. Effect of FYM, planting methods and fertilizer levelson rainfed wheat. Crop Res. Hisar. 20 (3) 534-536.
[19] Peel, M. C. Finlayson, B. L. McMahon, T. A. (2007). Updated world map of theKöppen-Geiger climate classification. Hydrol. Earth Syst. Sci. 11: 1633-1644.

[20] Shaaban, S. M. 2006. Effect of organic and inorganic nitrogen fertilizer on wheat underwater regime. J. Appl. Sci. Res. 2: 650-656.

[21] Vyas, S. H., M. M. Modhwadia and V. D. Khanpara. 1997. Integrated nutrient managementin wheat. Gujarat Agric. Uni. Res. J. 23 (1): 12-18.

[22] Zougmore, R., N. Fujio and H. Akira. 2006. Nutrient uptakes and maize productivity asaffected by tillage system and cover crops in a subtropical climate at Ishigaki, Okinawa, Japan. Soil Sci. \& Plant Nutrition. 52: 509-518. 